Supporting Information

\title{
Investigation of Surface Alkylation Strategy in SOMC : An In-situ generation of a Silica-Supported Tungsten Methyl Catalyst for Cyclooctane Metathesis
}

\author{
Ali Hamieh ${ }^{\dagger}$ Raju Dey, ${ }^{\dagger}$ Manoja K. Samantaray, ${ }^{\dagger}$ Safwat Abdel-Azeim, ${ }^{\dagger}$ Edy Abou-Hamad,${ }^{\dagger}$ \\ Yin Chen, ${ }^{\dagger \#}$ Jérémie D. A. Pelletier, ${ }^{\dagger}$ Luigi Cavallo, ${ }^{\dagger}$ Jean-Marie Basset* ${ }^{\dagger}$ \\ ${ }^{\dagger}$ King Abdullah University of Science and Technology (KAUST), KAUST Catalysis Center (KCC), Thuwal 23955- \\ 6900, Saudi Arabia. \\ "Present address: Central South University, Department of Chemistry and Chemical Engineering, Changsha 410083, \\ Hunan, China.
}

\section{Contents}

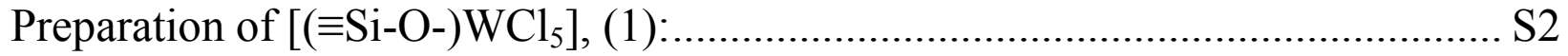

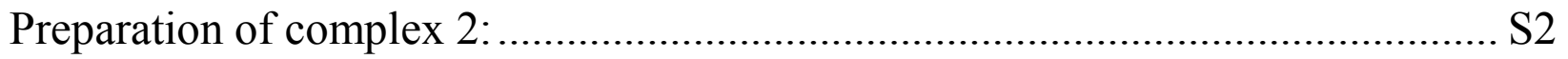

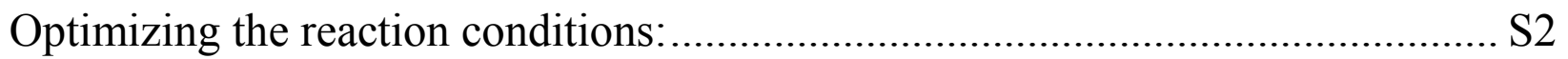

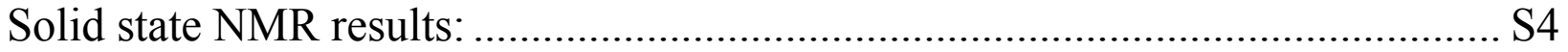

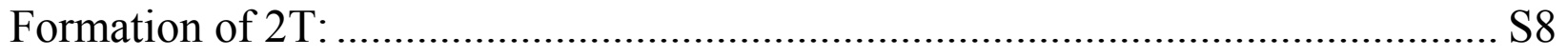

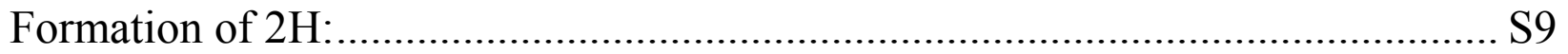

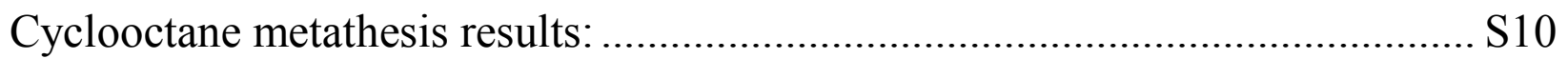

DFT Calculation results and related data:........................................................ S11

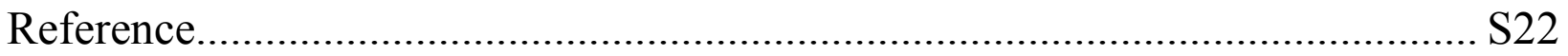




\section{Preparation of [( $\left.=\mathrm{Si}-\mathrm{O}-) \mathrm{WCl}_{5}\right],(\mathbf{1})$ :}

In a double Schlenk, a solution of $\mathrm{WCl}_{6}(396 \mathrm{mg}, 1 \mathrm{mmol}, 1.1$ equivalent with respect to the amount of surface-accessible silanols) in dichloromethane $(25 \mathrm{ml})$ was allowed to react with $\mathrm{SiO}_{2-700}(3.0 \mathrm{~g})$ at $25^{\circ} \mathrm{C}$ for $2 \mathrm{~h}$. This reaction was performed under mild dynamic vacuum conditions to remove the $\mathrm{HCl}$ produced during the reaction. At the end of the reaction, the resulting orange solid (1) was washed with dichloromethane $(3 \times 20 \mathrm{ml})$ and dried under a dynamic vacuum $\left(<10^{-5}\right.$ Torr, $2 \mathrm{~h}$ ). Elemental analysis found $\mathrm{W} 3.97 \%$; $\mathrm{Cl} 3.8 \%$. Determination of chloride was performed on $1(500 \mathrm{mg})$ inside a tight schlenk equipped with septum. A defined amount of water was introduced and kept for an hour to react completely. The gas generated during the reaction was then trapped to another schlenk containing $\mathrm{AgNO}_{3}(130 \mathrm{mg})$ solution. The solution was kept again for an hour with mild agitation. The solution was washed with water and $\mathrm{AgCl}$ was collected and its weight determined after drying inside $120^{\circ} \mathrm{C}$ oven $(70 \mathrm{mg}, 0.488$ mmol).

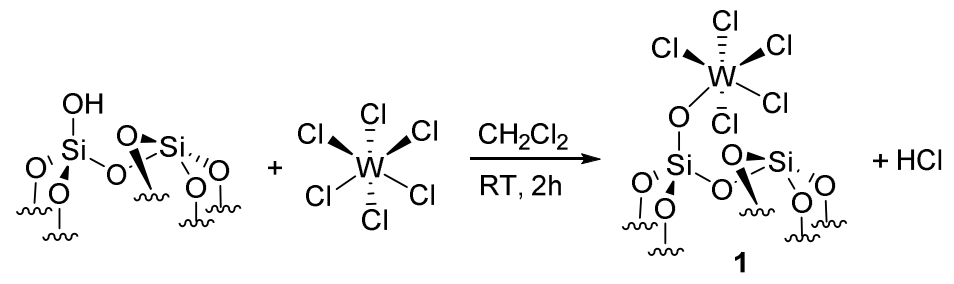

\section{Preparation of complex 2:}

[( $\left.=\mathrm{Si}-\mathrm{O}-) \mathrm{WCl}_{5}\right](1.0 \mathrm{~g}, \mathrm{~W}$ contain: $0.3 \mathrm{mmol})$ was introduced into a double schlenk inside the glovebox along with $20 \mathrm{ml}$ dichloromethane. A solution of $\mathrm{ZnMe}_{2}(0.75 \mathrm{mmol})$ in hexane was added dropwise at $25^{\circ} \mathrm{C}$ and stirred for specific duration (15 min, or 1, 2, 4, 12 hours). After completion of the reaction, the resulting solid (2) was filtered and thoroughly washed with dichloromethane. The complex was then dried under dynamic vacuum $\left(<10^{-5}\right.$ Torr $)$ conditions for 2 h. ${ }^{1} \mathrm{H}$ MAS SS-NMR $(400 \mathrm{MHz}, 298 \mathrm{~K}): \delta(\mathrm{ppm})-0.1\left(\mathrm{CH}_{3}\right), 1.3\left(\mathrm{CH}_{3}\right), 2.0\left(\mathrm{CH}_{3}\right), 2.2$ $\left(\mathrm{CH}_{3}\right) .{ }^{13} \mathrm{C}$ CP-MAS SS-NMR $(400 \mathrm{MHz}, 298 \mathrm{~K}): \delta(\mathrm{ppm}) 46\left(\mathrm{CH}_{3}\right), 53\left(\mathrm{CH}_{3}\right), 82\left(\mathrm{CH}_{3}\right)$. Elemental analysis of complex 2 gave $3.63 \% \mathrm{~W}, 0.87 \% \mathrm{C}, 2.34 \% \mathrm{Zn}, 0.13 \% \mathrm{H}$ and $2.07 \% \mathrm{Cl}$, with a ratio of $\mathrm{C} / \mathrm{W}=3.7$ and a ratio of $\mathrm{Cl} / \mathrm{Zn}=1.7, \mathrm{Zn} / \mathrm{W}=1.8$. Gas quantification of methane $(0.57 \mathrm{mmol})$ evolved from the hydrolysis of 2 showed a ratio of carbon to tungsten equal $2.9 \pm 0.2$.

\section{Optimizing the reaction conditions:}

Several alkylating agents such as $\mathrm{SnMe}_{4}, \mathrm{MeLi}, \mathrm{Al}_{2} \mathrm{Me}_{6}$, and $\mathrm{ZnMe}_{2}$ were tested to methylate 1 . However, it was observed that tetramethyl tin weakly reactive toward complex $\mathbf{1}$ at room temperature, whereas $\mathrm{MeLi}$ and $\mathrm{Al}_{2} \mathrm{Me}_{6}$ both are react violently with silica support to produce a 
large amount of Si-Me and $\mathrm{Si}-\mathrm{Me}_{2}$. Thus, $\mathrm{SnMe}_{4}, \mathrm{MeLi}$, and $\mathrm{Al}_{2} \mathrm{Me}_{6}$ were not considered for methylating agent. On the other hand, dimethylzinc was found to be more reactive than tetramethyl tin and milder than $\mathrm{MeLi}$ and $\mathrm{Al}_{2} \mathrm{Me}_{6}$ toward the support and thus consider for methylating agent. Several other parameters e.g. temperature, duration of the reaction, the amount of methylating agent and solvents were tested to find out the optimum reaction conditions. Here we report some of the conducted reactions with different conditions where we only reveal carbon NMR for simplicity. We found that the reaction is best using 2.5 equivalents of $\mathrm{ZnMe}_{2}$ in dichloromethane at room temperature or low temperature $\left(-40^{\circ} \mathrm{C}\right)$. The reaction was completed in a very short time (15 minutes).

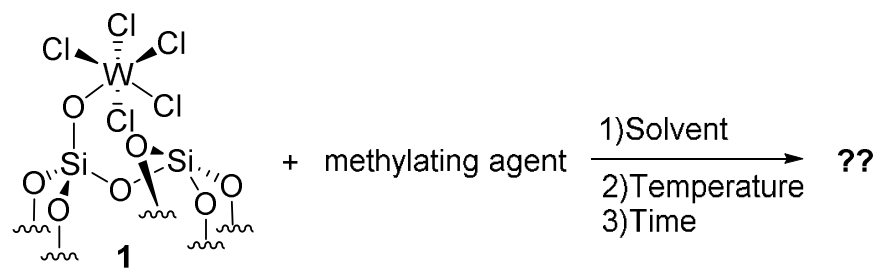

Table S1: Optimization of methylating agent.

\begin{tabular}{|c|l|}
\hline Methylating agent & \multicolumn{1}{c|}{ Remarks } \\
\hline $\mathrm{SnMe}_{4}$ & weakly reactive toward starting complex \\
\hline $\mathrm{MeLi}$ & react violently with silica support \\
\hline $\mathrm{Al}_{2} \mathrm{Me}_{6}$ & react violently with silica support \\
\hline $\mathrm{ZnMe}_{2}$ & $\begin{array}{l}\text { found reactive with metal-halide and very less reactivity with the } \\
\text { support }\end{array}$ \\
\hline
\end{tabular}

\section{Preparation of $\mathrm{Zn}\left({ }^{13} \mathrm{CH}_{3}\right)_{2}$}

In a $200 \mathrm{~mL}$ Schlenk, $15 \mathrm{~mL}$ of $1.6 \mathrm{M} \mathrm{BuLi}$ was taken under argon, and to that was added dropwise $3.4 \mathrm{~g}(24 \mathrm{mmol})$ of ${ }^{13} \mathrm{MeI}$ diluted in $25 \mathrm{~mL}$ of pentane at $-20{ }^{\circ} \mathrm{C}$ with stirring. A white precipitate formed immediately, and the solution was stirred for another 3 hours. The precipitate was then filtered and dried under a vacuum to produce a white solid $\left({ }^{13} \mathrm{MeLi}\right)$. A small amount of ${ }^{13} \mathrm{MeLi}$ was taken and titrated with deoxygenated water to quantify the amount of methyl lithium present by quantifying the release of methane (around $55 \%{ }^{13} \mathrm{MeLi}$ was found). In another double Schlenk, ${ }^{13} \mathrm{MeLi}$ (22 mmol, $484 \mathrm{mg}$ ) was added with $20 \mathrm{~mL}$ of pentane, and to that a solution of anhydrous $\mathrm{ZnCl}_{2}(10 \mathrm{mmol}$ in $10 \mathrm{~mL})$ was added at $-20{ }^{\circ} \mathrm{C}$. The reaction was allowed to reach at room temperature slowly and remained at that temperature for another 2 days. The volatiles were then trapped into a schlenk, and the dimethylzinc was collected as pentane solution. 


\section{Solid state NMR results:}
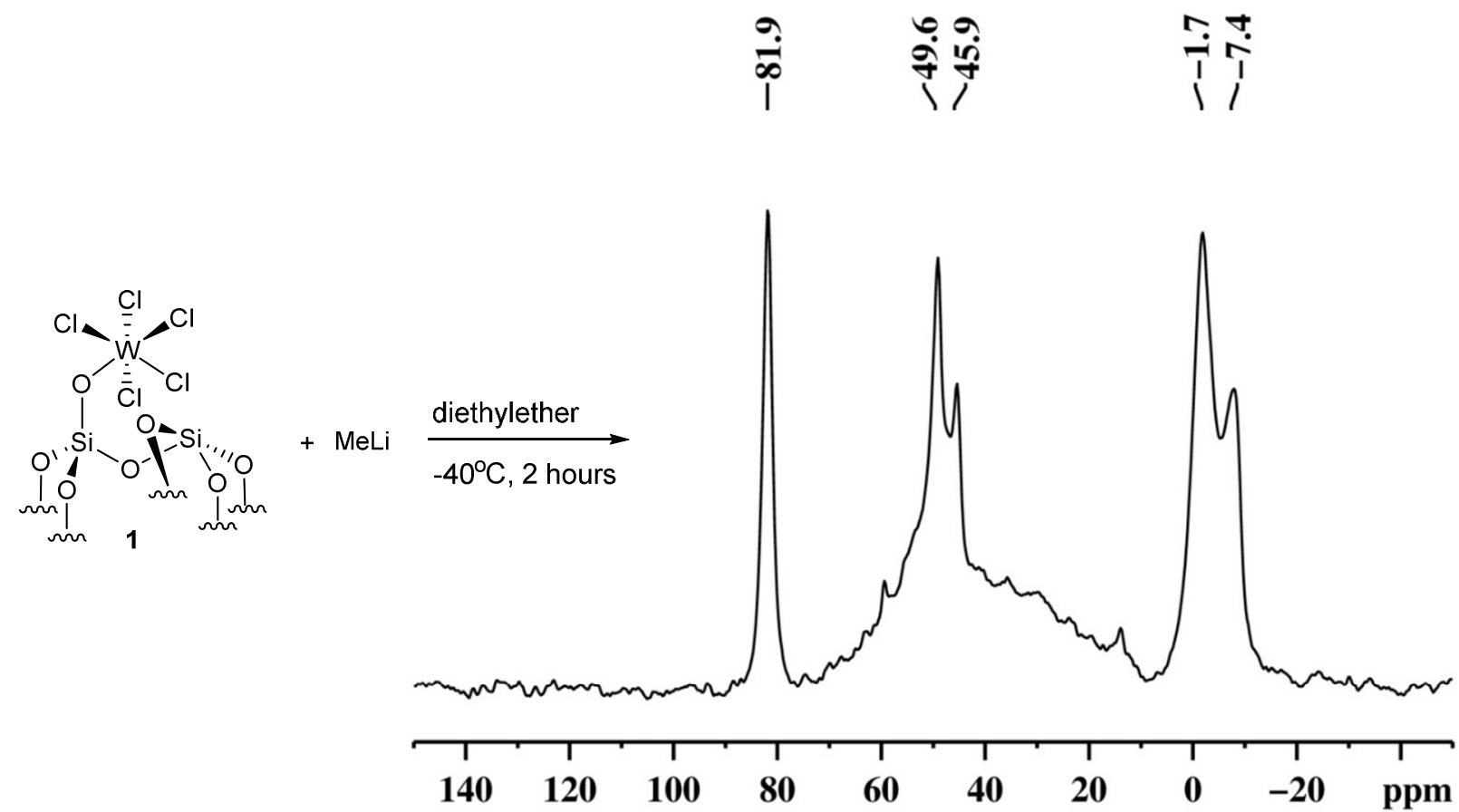

Figure S1: One-dimensional ${ }^{13} \mathrm{C} \mathrm{CP} / \mathrm{MAS}$ NMR spectra (600 MHz ${ }^{1} \mathrm{H}$ frequency) of 1 after treating with carbon enriched MeLi, peaks at -1.7 and -7.4 ppm are attributed to -Si-Me and $\mathrm{Si}(\mathrm{Me})_{2}$. 

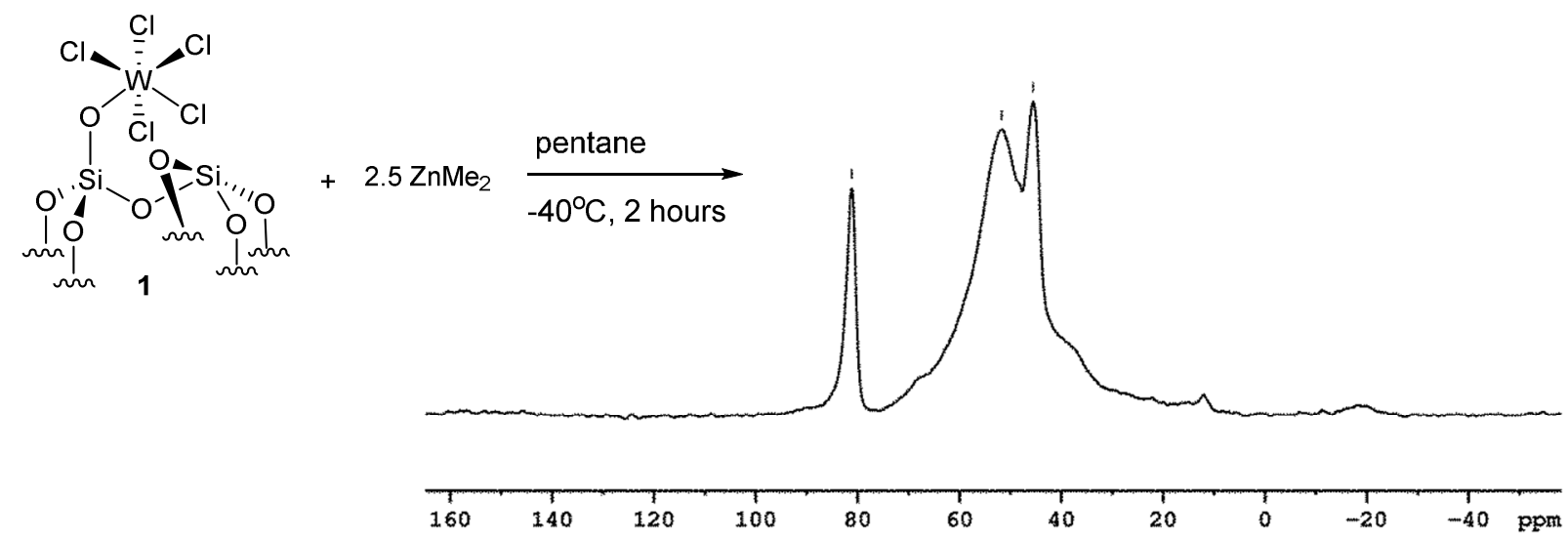

Figure S2: One-dimensional ${ }^{13} \mathrm{C} \mathrm{CP} / \mathrm{MAS} N M R$ spectra (600 MHz ${ }^{1} \mathrm{H}$ frequency) of 1 after treating with 2.5 equivalents of $\mathrm{ZnMe}_{2}$ in pentane.
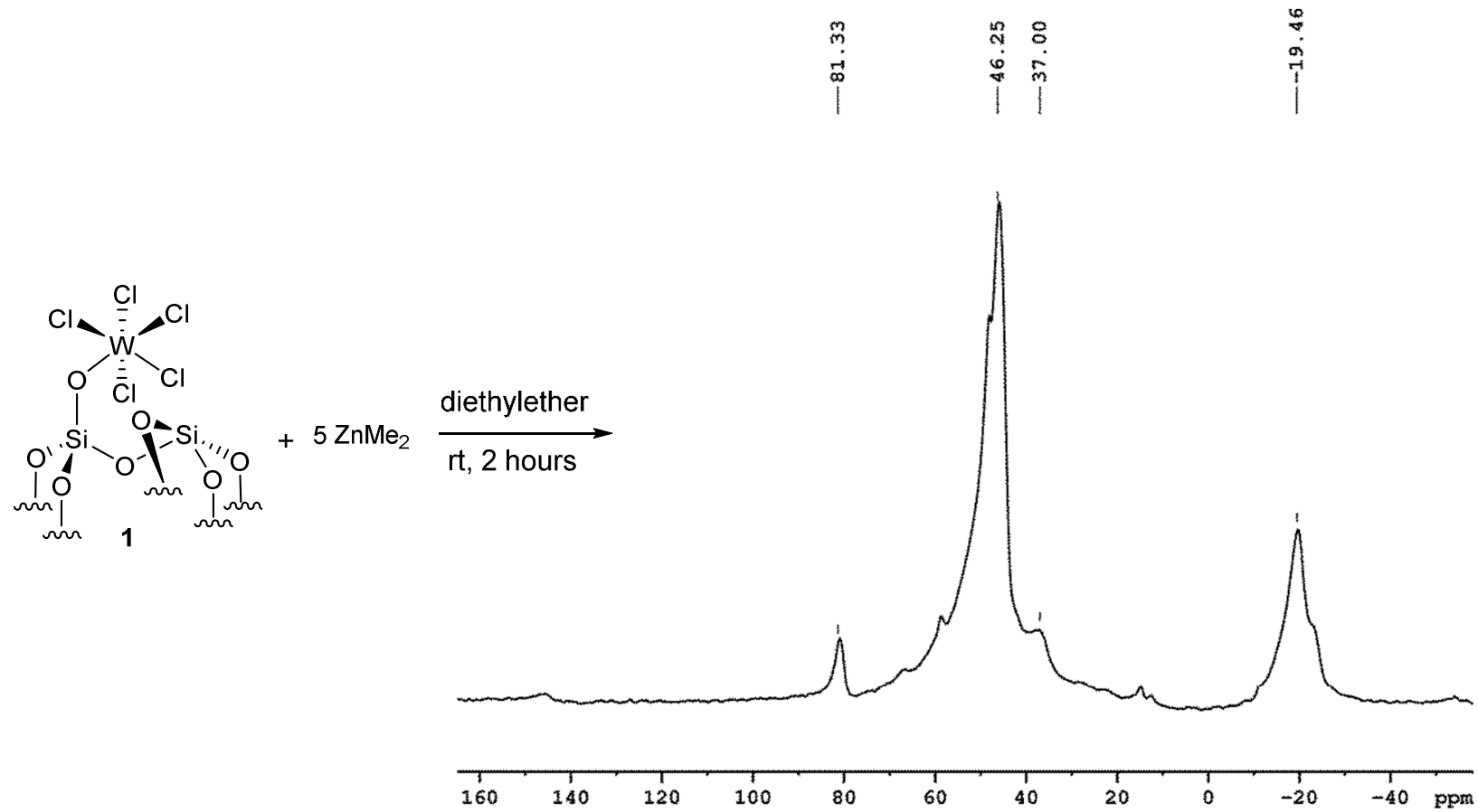

Figure S3: One-dimensional ${ }^{13} \mathrm{C} \mathrm{CP} / \mathrm{MAS}$ NMR spectra of 1 (600 MHz ${ }^{1} \mathrm{H}$ frequency) after treating with 5 equivalents of $\mathrm{ZnMe}_{2}$ in diethyl ether. 


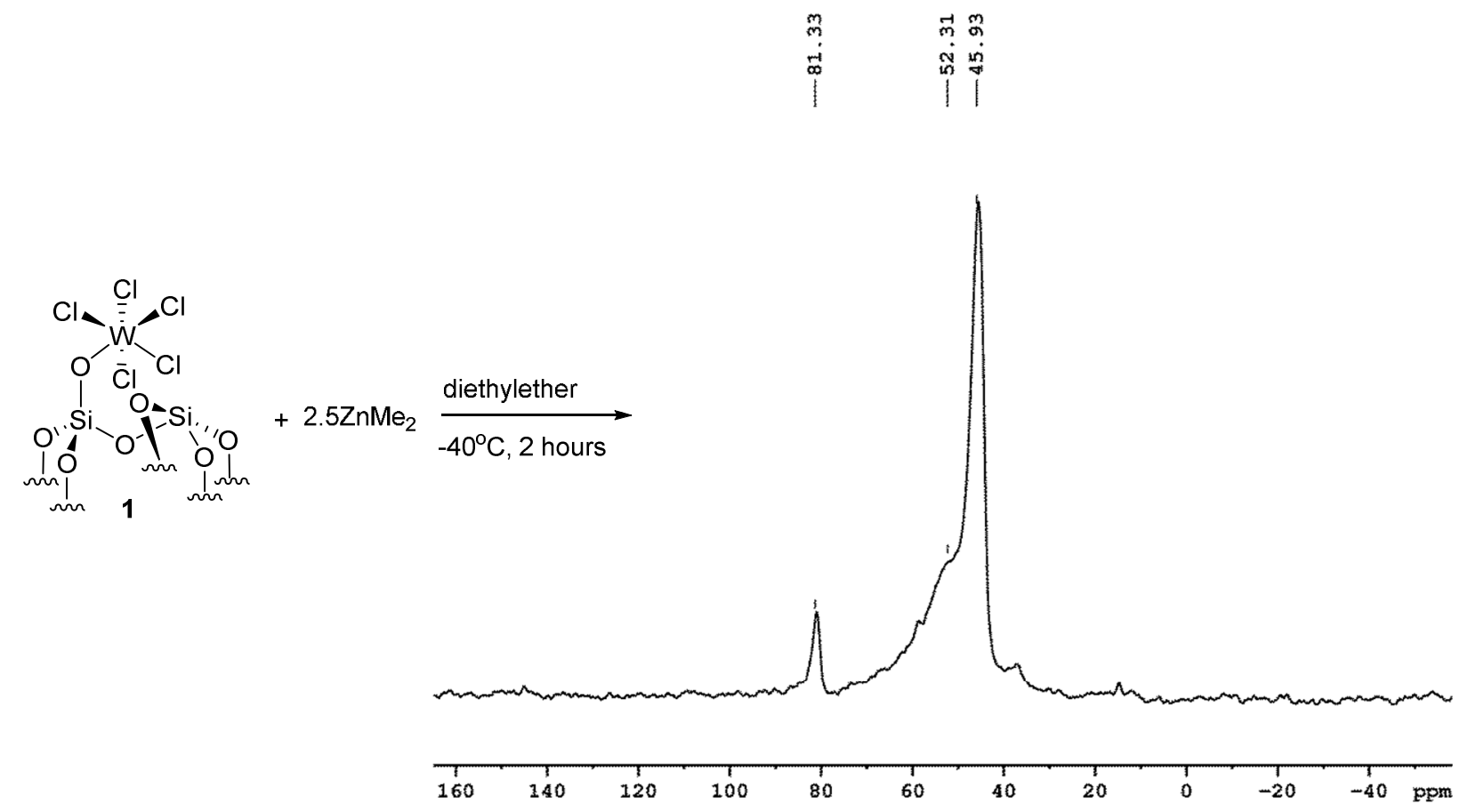

Figure S4: One-dimensional ${ }^{13} \mathrm{C} \mathrm{CP} / \mathrm{MAS}$ NMR spectra of 1 (600 MHz ${ }^{1} \mathrm{H}$ frequency) after treating with 2.5 equivalents of $\mathrm{ZnMe}_{2}$ in diethyl ether.
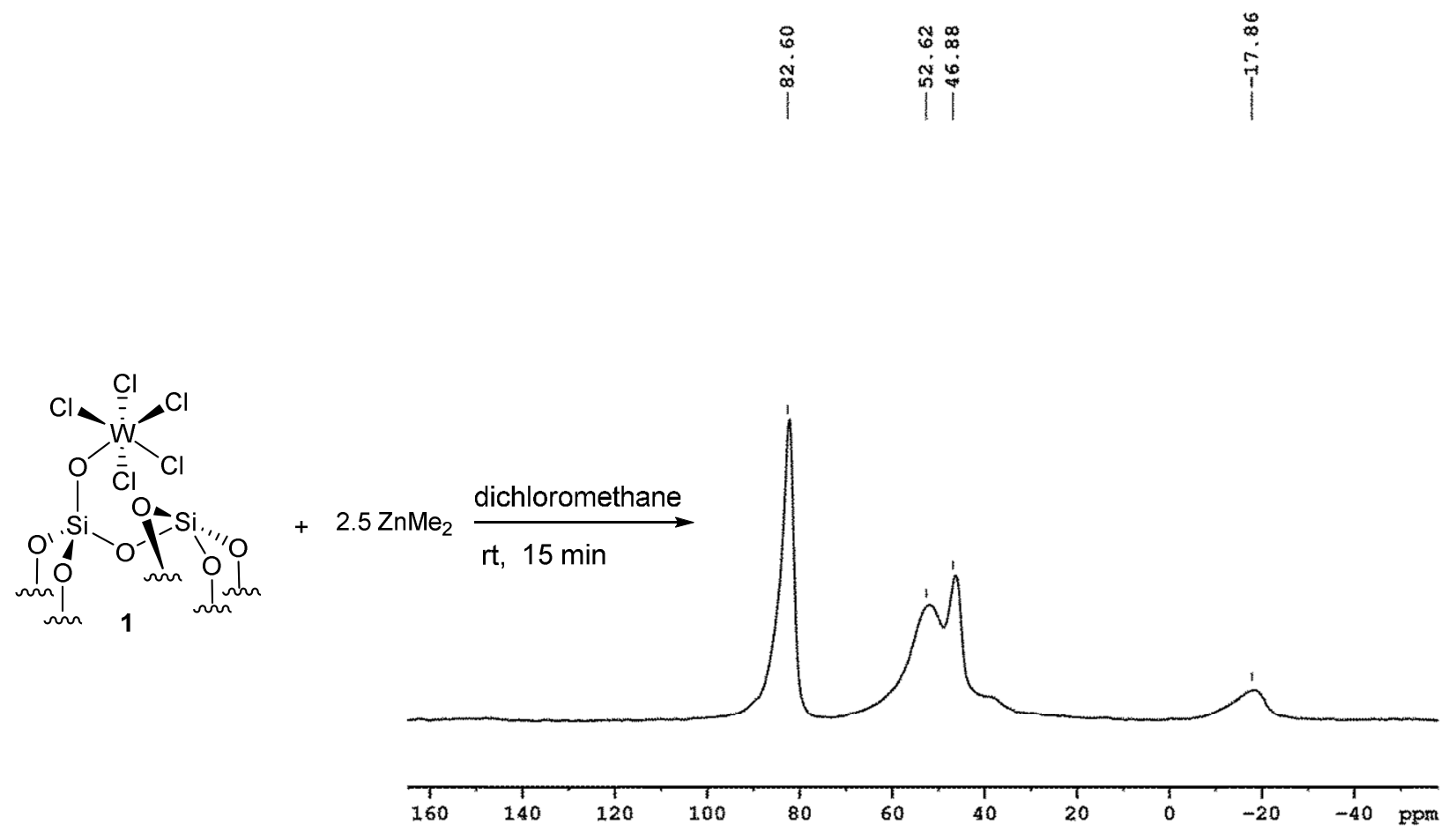

Figure S5: One-dimensional ${ }^{13} \mathrm{C} \mathrm{CP} / \mathrm{MAS}$ NMR spectra of 1 (600 MHz ${ }^{1} \mathrm{H}$ frequency) after treating with 2.5 equivalents of $97 \%$ carbon enriched $\mathrm{ZnMe}_{2}$ in dichloromethane for $15 \mathrm{~min}$. 


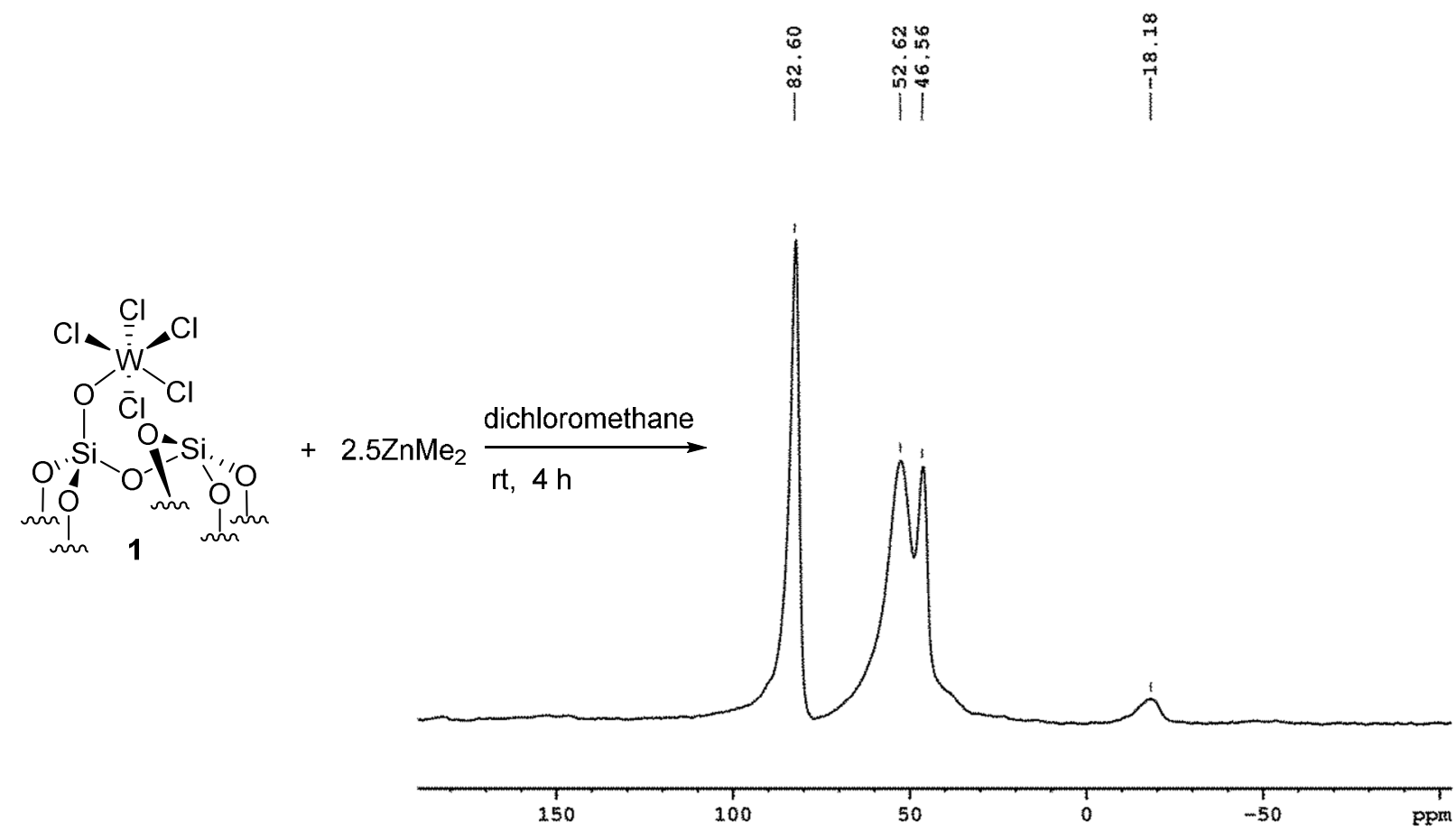

Figure S6: One-dimensional ${ }^{13} \mathrm{C} \mathrm{CP} / \mathrm{MAS}$ NMR spectra of 1 (600 MHz ${ }^{1} \mathrm{H}$ frequency) after treating with 2.5 equivalents of carbon enriched $\mathrm{ZnMe}_{2}(97 \%)$ in dichloromethane for 4 hours.

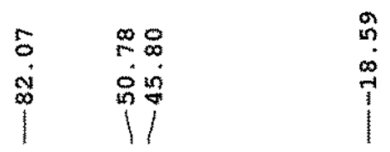

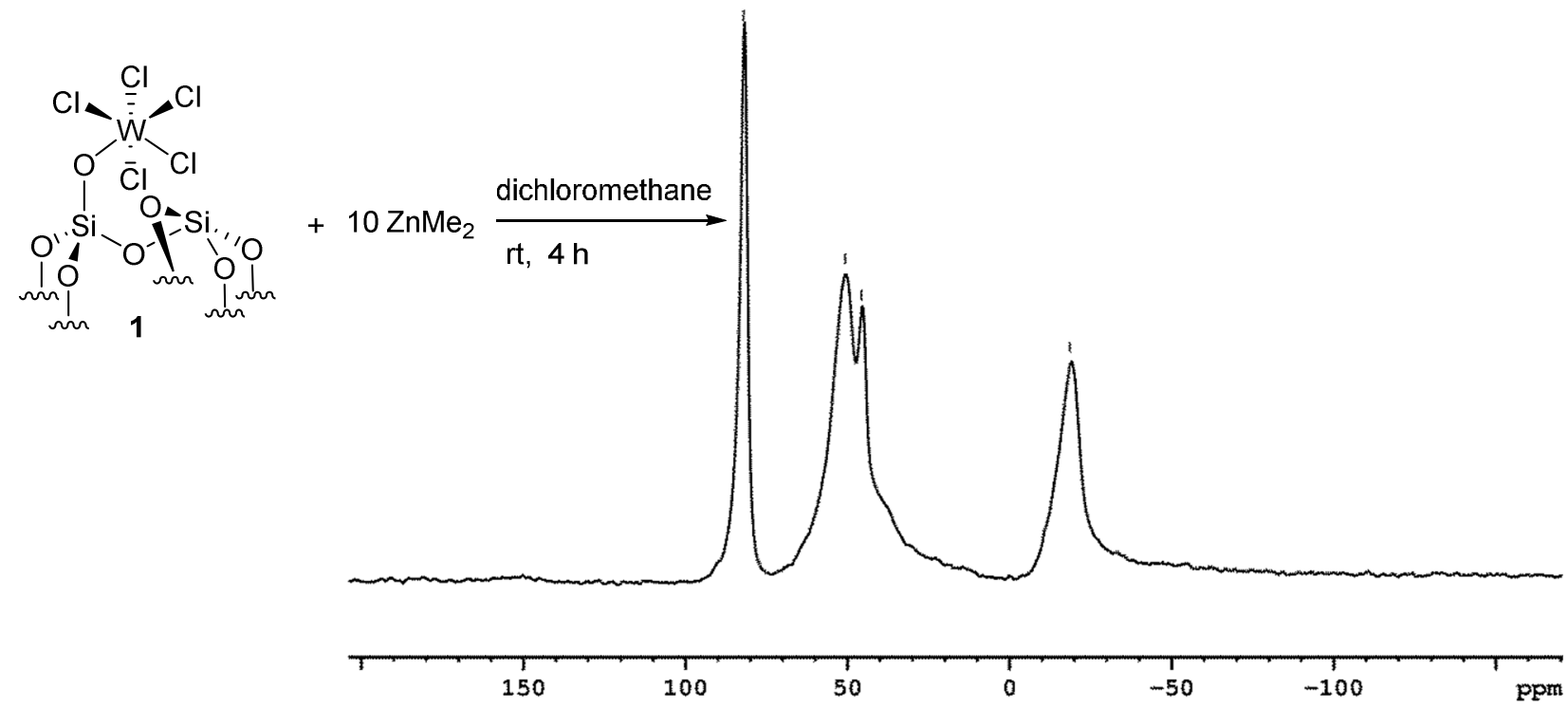

Figure S7: One-dimensional ${ }^{13} \mathrm{C} \mathrm{CP} / \mathrm{MAS} N M R$ spectra of 1 (600 MHz ${ }^{1} \mathrm{H}$ frequency) after treating with $>5$ equivalents of carbon enriched $\mathrm{ZnMe}_{2}(97 \%)$ in dichloromethane for 4 hours. 


\section{Formation of 2T:}

In a glass reactor, $2(1.0 \mathrm{~g})$ was introduce inside the glovebox and was heated at $150^{\circ} \mathrm{C}$ (ramp $60^{\circ} \mathrm{C} / \mathrm{h}$ ) for $12 \mathrm{~h}$ to produce a dark gray powder $(\mathbf{2 T})$. The released gas identified by GC was mainly methane. Glass reactor was evacuated and NMR was conducted on the powder.

(A comparison with previously reported ${ }^{1}$ well-defined tungsten pentamethyl partially decomposed after several days at room temperature was carried out and a similar trend of the peaks at 46 and 50 ppm was noticed.)

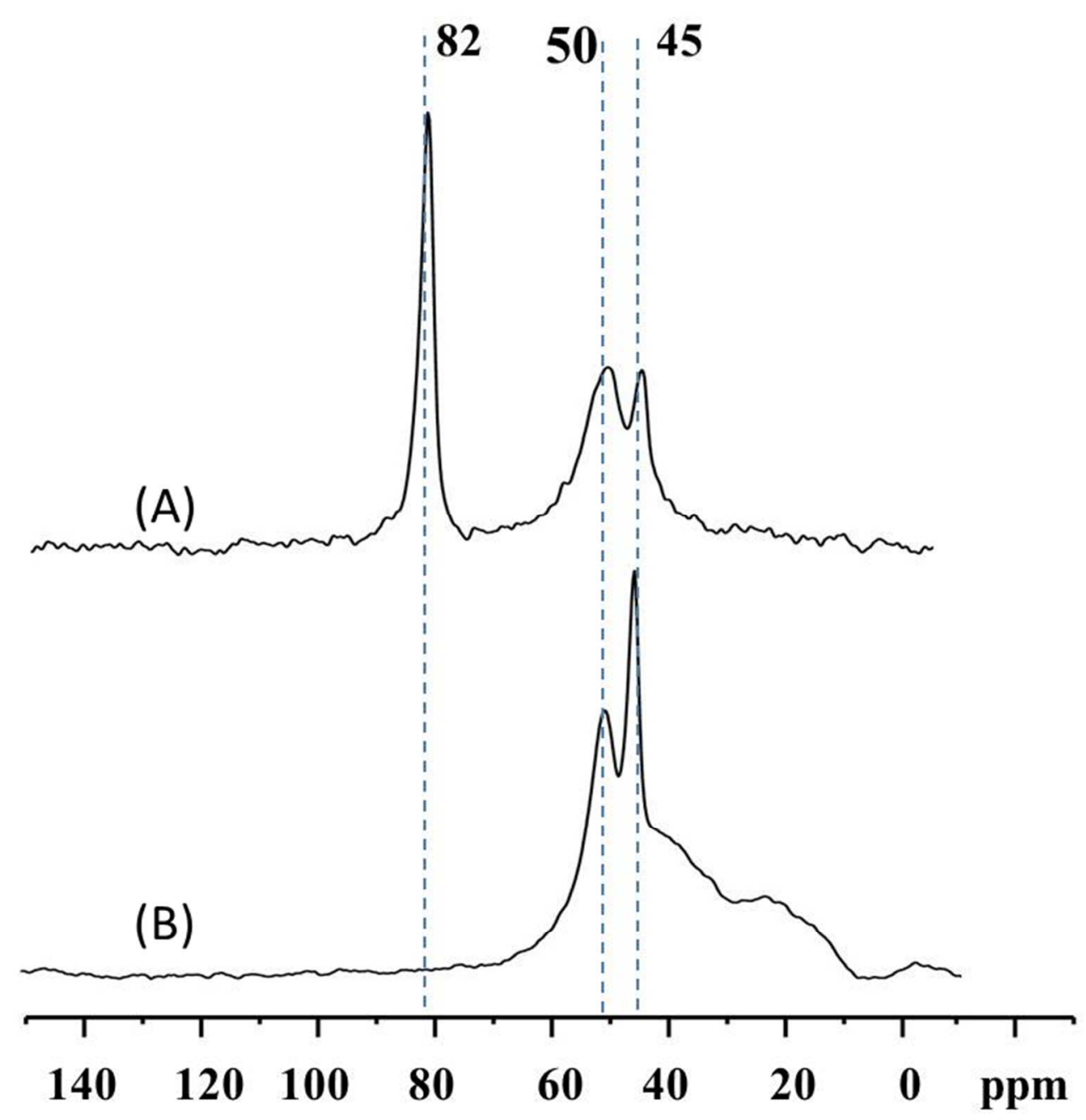

Figure S8: (A) One-dimensional ${ }^{13} \mathrm{C} \mathrm{CP} / \mathrm{MAS}$ NMR spectra (600 $\mathrm{MHz}{ }^{1} \mathrm{H}$ frequency) of methylated 2 complex, prepared by ${ }^{13} \mathrm{C}$ labeled dimethyl zinc with a $10 \mathrm{KHz}$ MAS frequency (a repetition delay $=5 \mathrm{~s}$, contact time $=2 \mathrm{~ms}$, line broadening $=80 \mathrm{~Hz}$ and number of scans = 10000). (B) One-dimensional ${ }^{13} \mathrm{C} \mathrm{CP} / \mathrm{MAS} N M R$ spectra of ${ }^{13} \mathrm{C}$ label methylated 2 after heating at $150^{\circ} \mathrm{C}$ for 2 hours (2T). 


\section{Formation of $\mathbf{2 H}$ :}

A pellet of $2(50 \mathrm{mg})$ was introduced into an IR cell $(150 \mathrm{ml})$ equipped with $\mathrm{CaF}_{2}$ windows and then evacuated. The IR cell tube then immersed into a solution of liquid nitrogen/ acetone solution for 5 minutes. Dried hydrogen was introduced at $-78^{\circ} \mathrm{C}(800 \mathrm{mbar})$ for 10 minutes and then evacuated and record the infrared spectra (similar results were obtained when hydrogenolysis reaction was repeated at room temperature) $\mathrm{CH}_{4}$ gas was detected by $\mathrm{GC}$ as a by-product after the reaction.

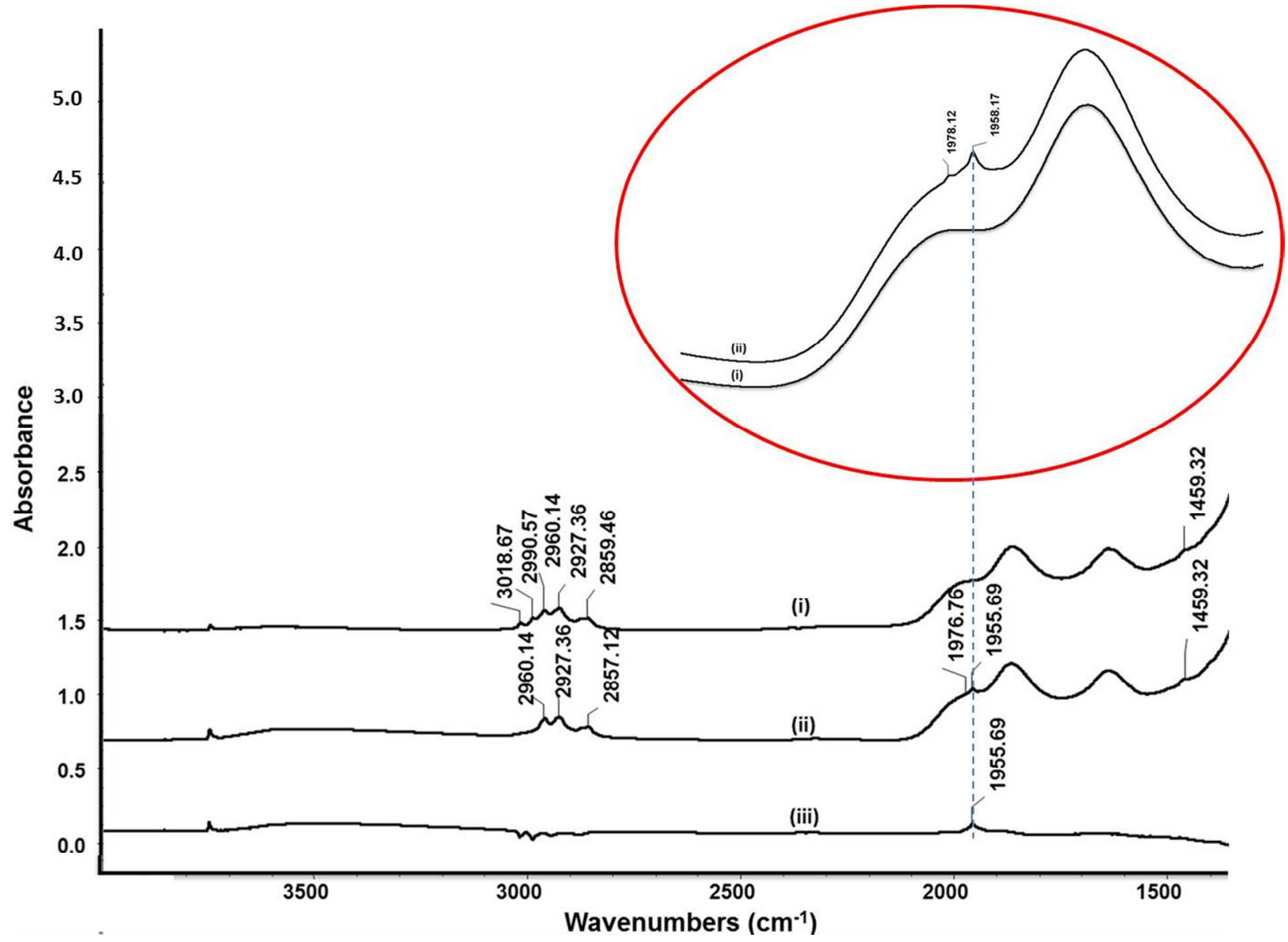

Figure S9: IR spectrum of (i) Complex 2, (ii) after hydrogenation of complex 2 with dried $\mathrm{H}_{2}$ at $78^{\circ} \mathrm{C}$, (iii) subtraction between (ii)-(i). 


\section{Cyclooctane metathesis results:}

Typical catalytic testing was performed using an ampoule filled with the catalyst (35 mg, W loading, $\left.0.017 \mathrm{mmol} . \mathrm{g}^{-1}\right)$ inside a glovebox and cyclooctane $(0.5 \mathrm{ml}, 3.7 \mathrm{mmol})$ was added to it. The ampoule was then sealed under vacuum, immersed in an oil bath and heated at $150^{\circ} \mathrm{C}$ for required time period, after the end of the catalytic run, the ampoules were frozen using liquid nitrogen. The mixture was quenched by adding a fixed amount of dichloromethane. The solution collected after filtration was analyzed by GC-FID and GC-MS.

This process was repeated with $\mathbf{2 H}$ and $\mathbf{2 T}$ and previously reported ${ }^{1}$ well-defined tungsten pentamethyl $\left(\left[\equiv \mathrm{SiO}-\mathrm{W}(\mathrm{Me})_{5}\right]\right.$, prepared by reacting $\mathrm{WMe}_{6}$ with $\mathrm{SiO}_{2-700}$

In two complementary runs, $\mathrm{ZnCl}_{2}$ and $\mathrm{ZnMe}_{2}$ were added to an ampule equipped with $\mathbf{2}$ and cyclooctane. In the case of $\mathrm{ZnCl}_{2}$ almost no change in the activity was observed. While the presence of $\mathrm{ZnMe}_{2}$ leads to no product formation.

Table S2: Summarized table showing the GC area of the reaction of different complexes with cyclooctane inside an ampule at $150^{\circ} \mathrm{C}$, TON was calculated. The area of each product by was added under its carbon number.

\begin{tabular}{|c|c|c|c|c|c|c|c|c|c|c|c|c|c|c|c|}
\hline & Mwt & vol & den & Swt & Mmoles & & & & & & & & & & \\
\hline & 112.2 & 0.5 & 0.83 & 0.415 & 3.70 & & & C & C Actual & $\% w t$ & & & & & \\
\hline & 183.84 & & & & & & & 1.00 & 0.0341 & 3.41 & & & & & \\
\hline C1 area & C/s Ratio & & & & & 0.0065 & $6 \mathrm{E}-06$ & 0.035 & 0.0012 & & & & & & \\
\hline 15000 & 570 & & & & & & & & & & & & & & \\
\hline \multirow[t]{3}{*}{1875} & & & & 112 & 42 & 56 & 70 & 84 & 98 & 126 & 140 & 154 & 168 & 182 & 196 \\
\hline & & & & & $\mathrm{C} 4$ & $\mathrm{C} 5$ & C6 & $\mathrm{C} 7$ & C9 & $\mathrm{C} 10$ & $\mathrm{C} 11$ & $\mathrm{C} 12$ & $\mathrm{C} 13$ & $\mathrm{C} 14$ & C15 \\
\hline & & & & 8 & 4 & 5 & 6 & 7 & 9 & 10 & 11 & 12 & 13 & 14 & 15 \\
\hline Complex (time in days) & TON & Conv & Mass B & 15000 & 7500 & 9375 & 11250 & 13125 & 16875 & 18750 & 20625 & 22500 & 24375 & 26250 & 28125 \\
\hline 0 & 0 & 0 & 0 & 15000 & 0 & 0 & 0 & 0 & 0 & 0 & 0 & 0 & 0 & 0 & 0 \\
\hline complex 2 (1d) & 18 & 3.2 & 98.4 & 14520 & 31.0 & & & 176.9 & 32.4 & 19.1 & & & & & 10.1 \\
\hline complex 2 (5d) & 70 & 12.3 & 95.6 & 13150 & 21.8 & 37.5 & 17.0 & 672.7 & 32.2 & 18.6 & 6.8 & 12.7 & 22.0 & 27.5 & 43.1 \\
\hline complex 2 (8d) & 74 & 13.1 & 97.0 & 13041 & 9.2 & 38.4 & 10.5 & 548.8 & 32.4 & 18.2 & 0.0 & 10.5 & 17.6 & 21.7 & 36.5 \\
\hline complex 2-hydride (5days) & 144 & 25.3 & 92.2 & 11200 & 17.8 & 105.6 & 0 & 1471.2 & 40.5 & 23.5 & 0 & 25.8 & 44 & 55.7 & 108.1 \\
\hline complex 2-decomposed (5days) & 84 & 14.7 & 94.4 & 12790 & 14.0 & 60.4 & 0.0 & 840.0 & 37.4 & 21.6 & 0.0 & 13.4 & 23.5 & 30.1 & 50.6 \\
\hline & & & & & & & & & & & & & & & \\
\hline
\end{tabular}

\begin{tabular}{|c|c|c|c|c|c|c|c|c|c|c|c|c|c|c|c|}
\hline 210 & 224 & 238 & 252 & 266 & 280 & 294 & 308 & 322 & 336 & 350 & 364 & 378 & 392 & 406 & 420 \\
\hline $\mathrm{C} 16$ & $\mathrm{C} 17$ & $\mathrm{C} 1 \mathrm{~s}$ & $\mathrm{C} 19$ & $\mathrm{C} 20$ & $\mathrm{C} 21$ & $\mathrm{C} 22$ & $\mathrm{C} 23$ & $\mathrm{C} 24$ & $\mathrm{C} 25$ & $\mathrm{C} 26$ & $\mathrm{C} 27$ & $\mathrm{C} 2 \mathrm{~S}$ & $\mathrm{C} 29$ & $\mathrm{C} 30$ & $\mathrm{C} 31$ \\
\hline 16 & 17 & 18 & 19 & 20 & 21 & 22 & 23 & 24 & 25 & 26 & 27 & 28 & 29 & 30 & 31 \\
\hline 30000 & 31875 & 33750 & 35625 & 37500 & 39375 & 41250 & 43125 & 45000 & 46875 & 48750 & 50625 & 52500 & 54375 & 56250 & 58125 \\
\hline 0 & 0 & 0 & 0 & 0 & 0 & 0 & 0 & 0 & 0 & 0 & 0 & 0 & 0 & 0 & 0 \\
\hline 12.0 & 12.8 & 11.8 & 10.7 & & & & & & & & & & & & \\
\hline 56.0 & 59.9 & 55.4 & 49.5 & 41.1 & 33.5 & 27.0 & 22.7 & 19.4 & 17.7 & 15.6 & 14.0 & 12.3 & 10.9 & 9.2 & 8.1 \\
\hline 49.1 & 51.9 & 46.9 & 40.9 & 33.2 & 26.3 & 20.7 & 17.5 & 15.0 & 15.7 & 12.2 & 11.0 & 9.6 & 8.2 & 6.5 & 6.2 \\
\hline 142.3 & 152.1 & 131.9 & 114.9 & 90.2 & 74.2 & 57.2 & 50 & 46.5 & 42.3 & 38.1 & 34.3 & 30.4 & 26.3 & 22.4 & 19.7 \\
\hline 62.8 & 65.4 & 57.8 & 50.7 & 41.6 & 34.1 & 27.8 & 24.0 & 21.0 & 23.7 & 17.5 & 15.7 & 13.8 & 12.4 & 10.2 & 11.7 \\
\hline & & & & & & & & & & & & & & & \\
\hline
\end{tabular}


DFT Calculation results and related data:

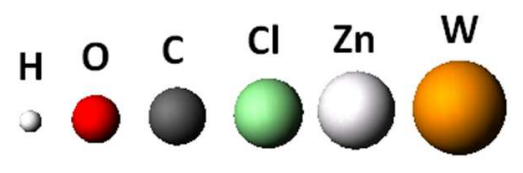

Table S3: NMR-DFT calculations of the partial substitution of [( $\left.(=\mathrm{Si}-\mathrm{O}-) \mathrm{WCl}_{5}\right]$

\begin{tabular}{|l|l|}
\hline \multicolumn{2}{|c|}{ NMR chemical shifts of partial substitution of [(三Si-O-) WCI $\mathbf{W C}_{5}$} \\
\hline Species & Chemical shift (ppm) \\
\hline [ESi-O-) & \\
\hline
\end{tabular}




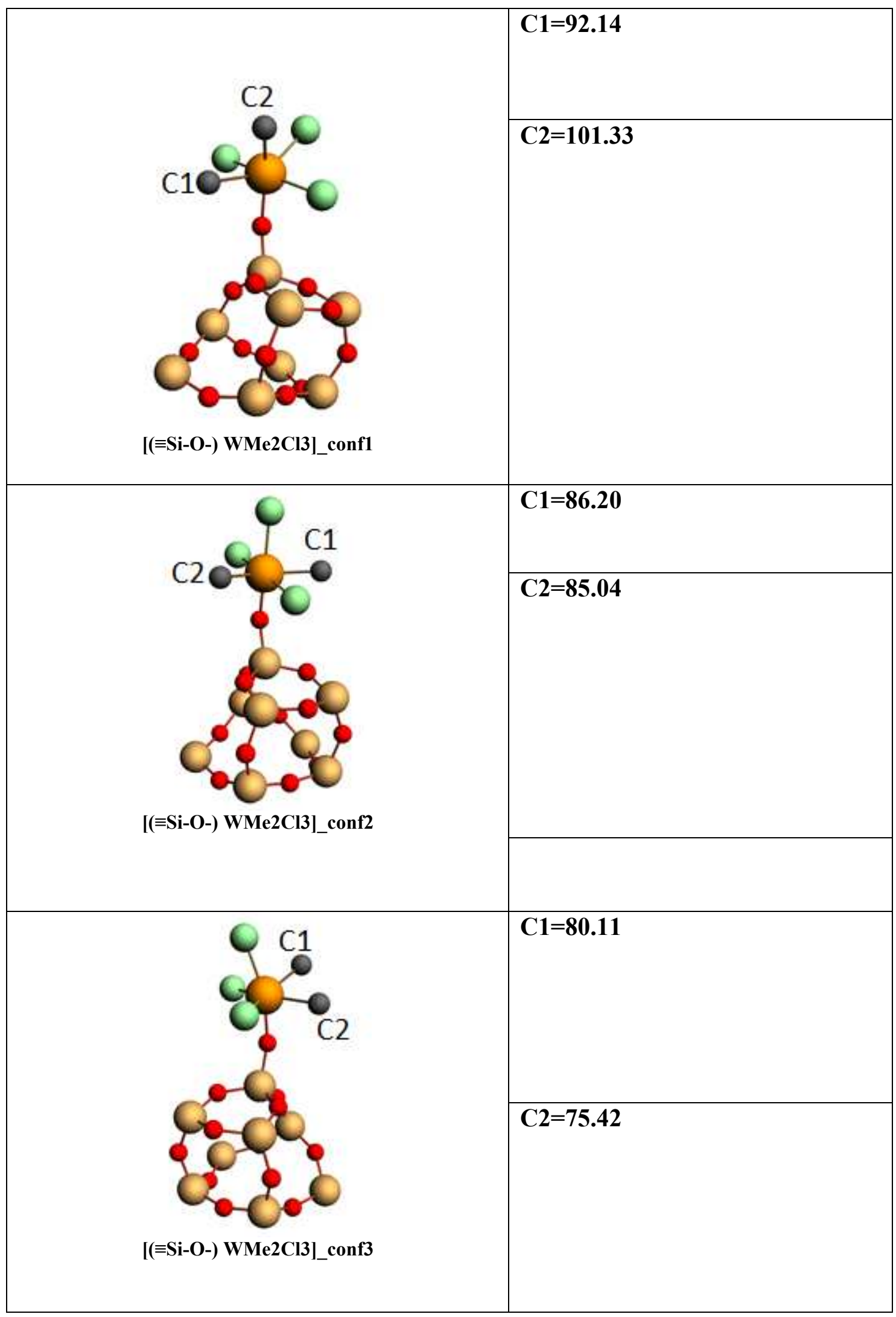




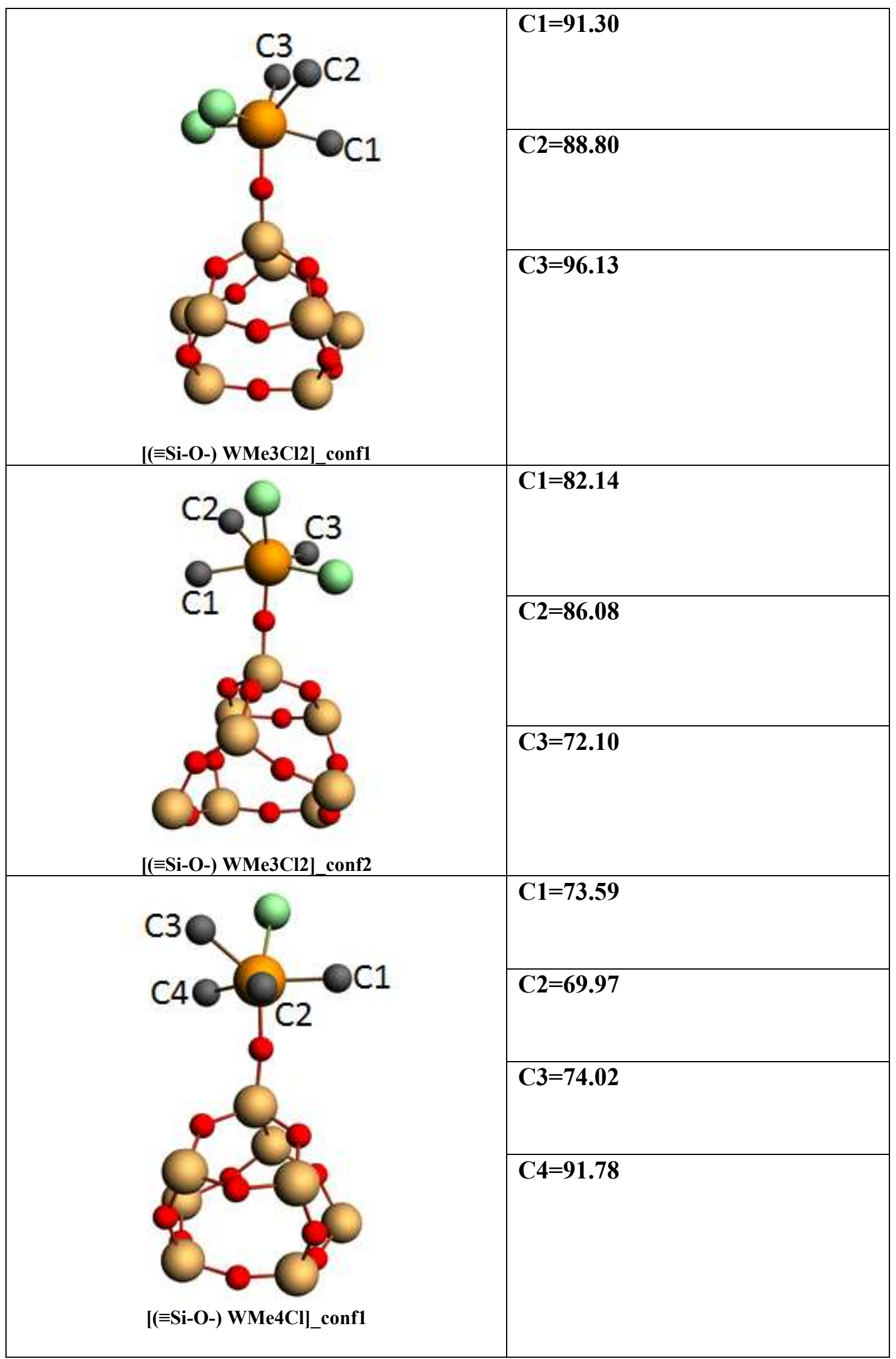




\begin{tabular}{|l|l|}
\hline$C 2=82.62$ \\
\hline$C 3=84.16$ \\
\hline$C 213$ \\
\hline$C 21$
\end{tabular}




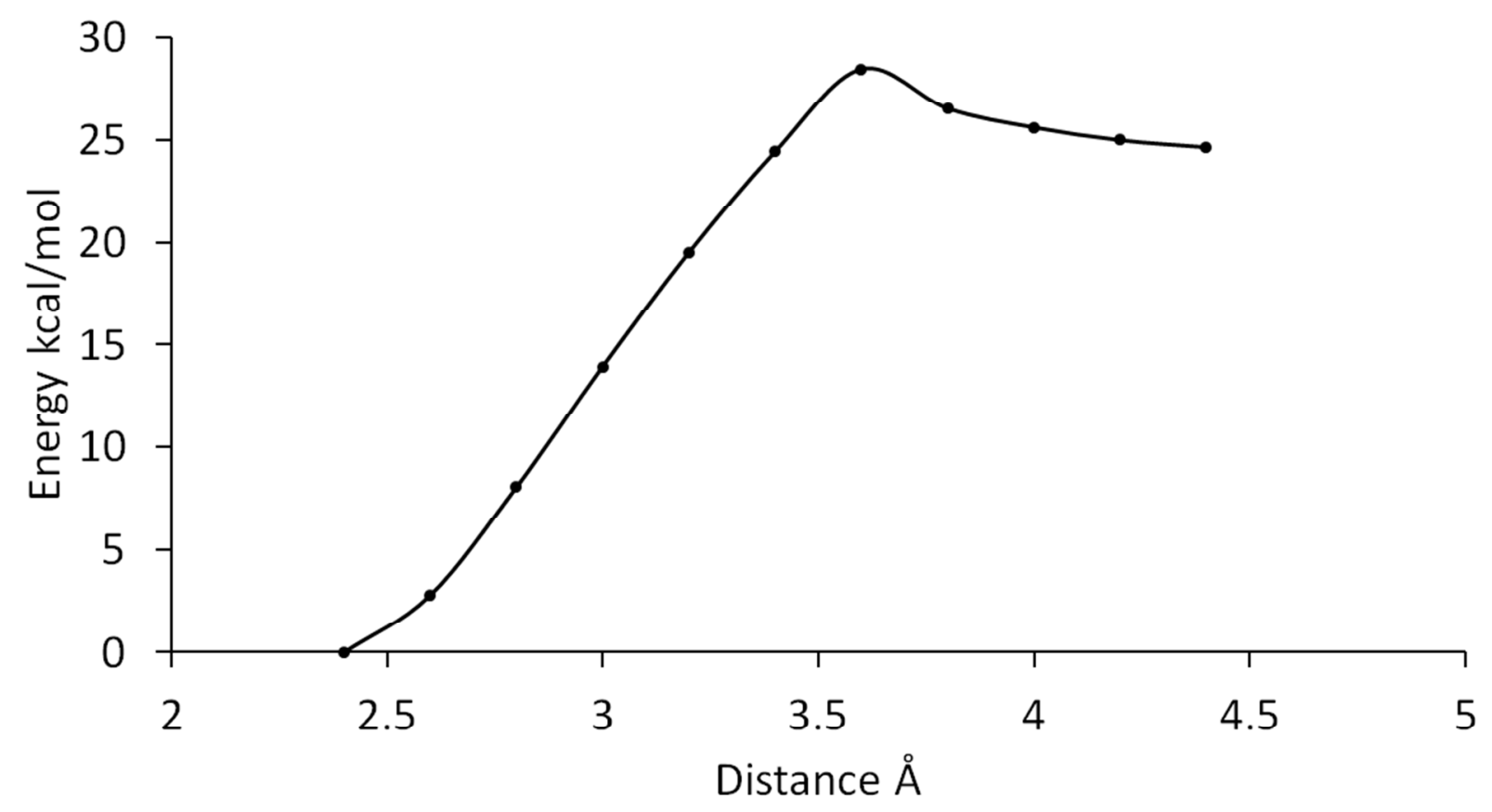

Figure S9: Relaxed scan of W-Cl bond using PBE/Def2-TZVP level of theory.

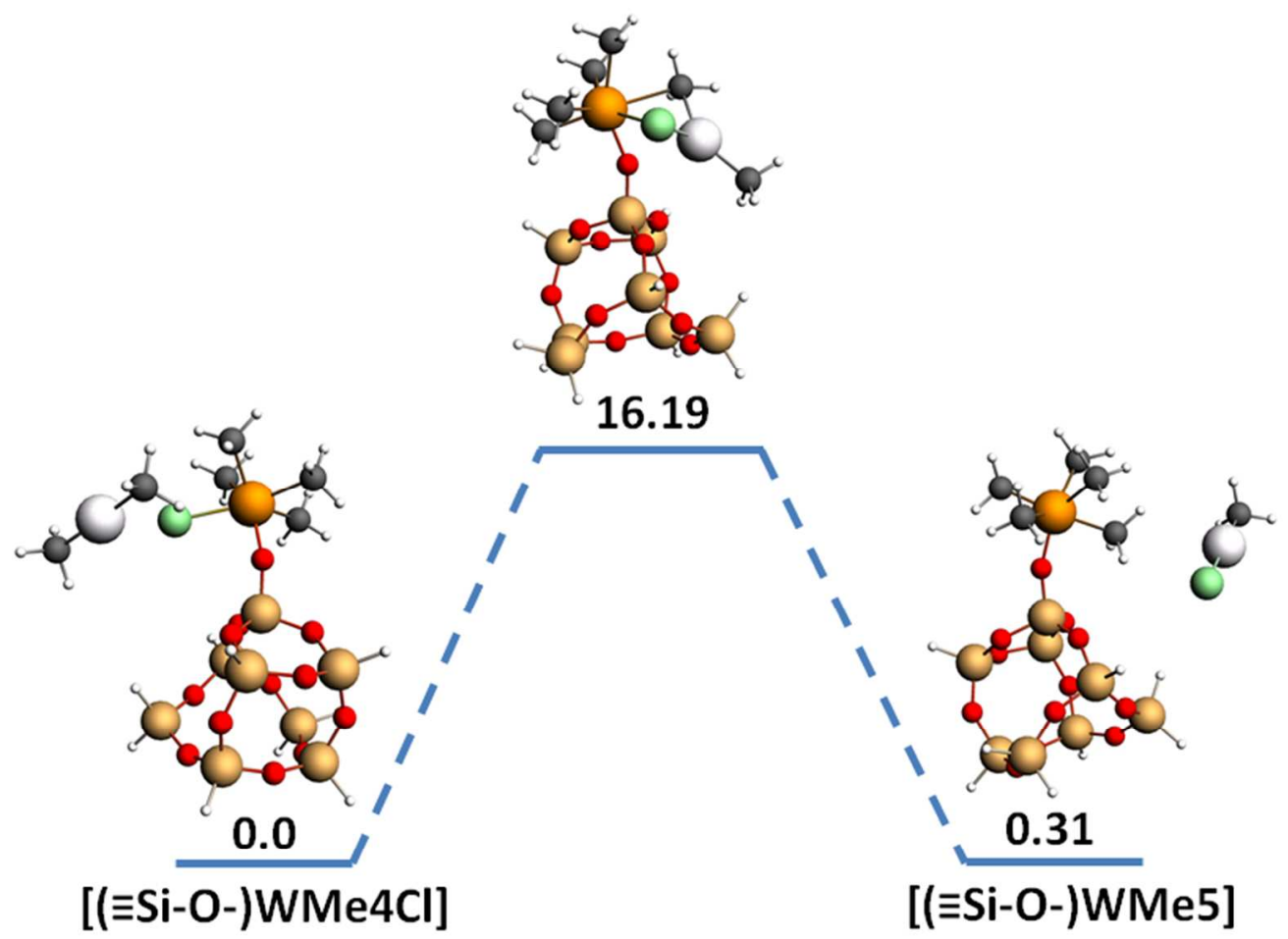

Figure S10: Interconversion of [(三Si-O-)WMe4Cl] to [(三Si-O-) WMe5] calculated using PBE/Def2 TZVP level of theory. 
Thermodynamics of carbene and carbyne reactions with $\mathrm{ZnCl}_{2}$ and $\mathrm{ZnMe}_{2}$.

$\underline{\text { Reaction of carbene with } \mathrm{ZnCl}_{2}} \underline{\text { and } \mathrm{ZnMe}} \underline{\underline{2}}$

$\left.\left[(\equiv \mathrm{Si}-\mathrm{O}-) \mathrm{WCH}_{2} \mathrm{Me} 2 \mathrm{Cl}\right]+\mathrm{ZnCl}_{2} \rightarrow[(\equiv \mathrm{Si}-\mathrm{O}-)) \mathrm{WCHMe}_{2} \mathrm{ZnCl}_{2}\right]+\mathrm{HCl} \quad \Delta \mathrm{G}=13.38$

$\left.\left[(\equiv \mathrm{Si}-\mathrm{O}-) \mathrm{WCH} 2 \mathrm{Me}_{2} \mathrm{Cl}\right]+\mathrm{ZnMe}_{2} \rightarrow[(\equiv \mathrm{Si}-\mathrm{O}-)) \mathrm{WCHMe}_{2} \mathrm{ZnClMe}\right]+\mathrm{CH}_{4} \quad \Delta \mathrm{G}=-20.64$

$\left.\left[(\equiv \mathrm{Si}-\mathrm{O}-) \mathrm{WCH}_{2} \mathrm{Me}_{3}\right]+\mathrm{ZnCl}_{2} \rightarrow[(\equiv \mathrm{Si}-\mathrm{O}-)) \mathrm{WCHMe}_{3} \mathrm{ZnCl}_{2}\right]+\mathrm{HCl} \quad \Delta \mathrm{G}=22.91$

$\left.\left[(\equiv \mathrm{Si}-\mathrm{O}-) \mathrm{WCH}_{2} \mathrm{Me}_{3}\right]+\mathrm{ZnMe}_{2} \rightarrow[(\equiv \mathrm{Si}-\mathrm{O}-)) \mathrm{WCHMe}_{3} \mathrm{ZnClMe}\right]+\mathrm{CH}_{4} \quad \Delta \mathrm{G}=-\mathbf{1 7 . 2 6}$

$\underline{\text { Reaction of carbyne with } \mathrm{ZnCl}_{2}} \underline{\text { and } \mathrm{ZnMe}_{2}}$

$\left.\left[(\equiv \mathrm{Si}-\mathrm{O}-) \mathrm{WCHMe}_{2} \mathrm{Cl}\right]+\mathrm{ZnCl}_{2} \rightarrow[(\equiv \mathrm{Si}-\mathrm{O}-)) \mathrm{WCMe}_{2} \mathrm{ZnCl}_{2}\right]+\mathrm{HCl} \quad \Delta \mathrm{G}=\mathbf{1 6 . 1 4}$

$\left.\left[(\equiv \mathrm{Si}-\mathrm{O}-) \mathrm{WCHMe}_{2} \mathrm{Cl}\right]+\mathrm{ZnMe}_{2} \rightarrow[(\equiv \mathrm{Si}-\mathrm{O}-)) \mathrm{WCMe}_{2} \mathrm{ZnClMe}\right]+\mathrm{CH}_{4} \quad \Delta \mathrm{G}=-\mathbf{1 4 . 0 1}$

$\left.\left[(\equiv \mathrm{Si}-\mathrm{O}-) \mathrm{WCHMe}_{3}\right]+\mathrm{ZnCl}_{2} \rightarrow[(\equiv \mathrm{Si}-\mathrm{O}-)) \mathrm{WCHMe}_{3} \mathrm{ZnCl}\right]+\mathrm{HCl} \quad \Delta \mathrm{G}=\mathbf{1 5 . 9 6}$

$\left[(\equiv \mathrm{Si}-\mathrm{O}-) \mathrm{WCHMe}_{3}\right]+\mathrm{ZnMe}_{2} \rightarrow\left[(\equiv \mathrm{Si}-\mathrm{O}-) \mathrm{WCHMe}_{3} \mathrm{ZnMe}\right]+\mathrm{CH}_{4} \quad \Delta \mathrm{G}=-\mathbf{1 5 . 6 0}$ 


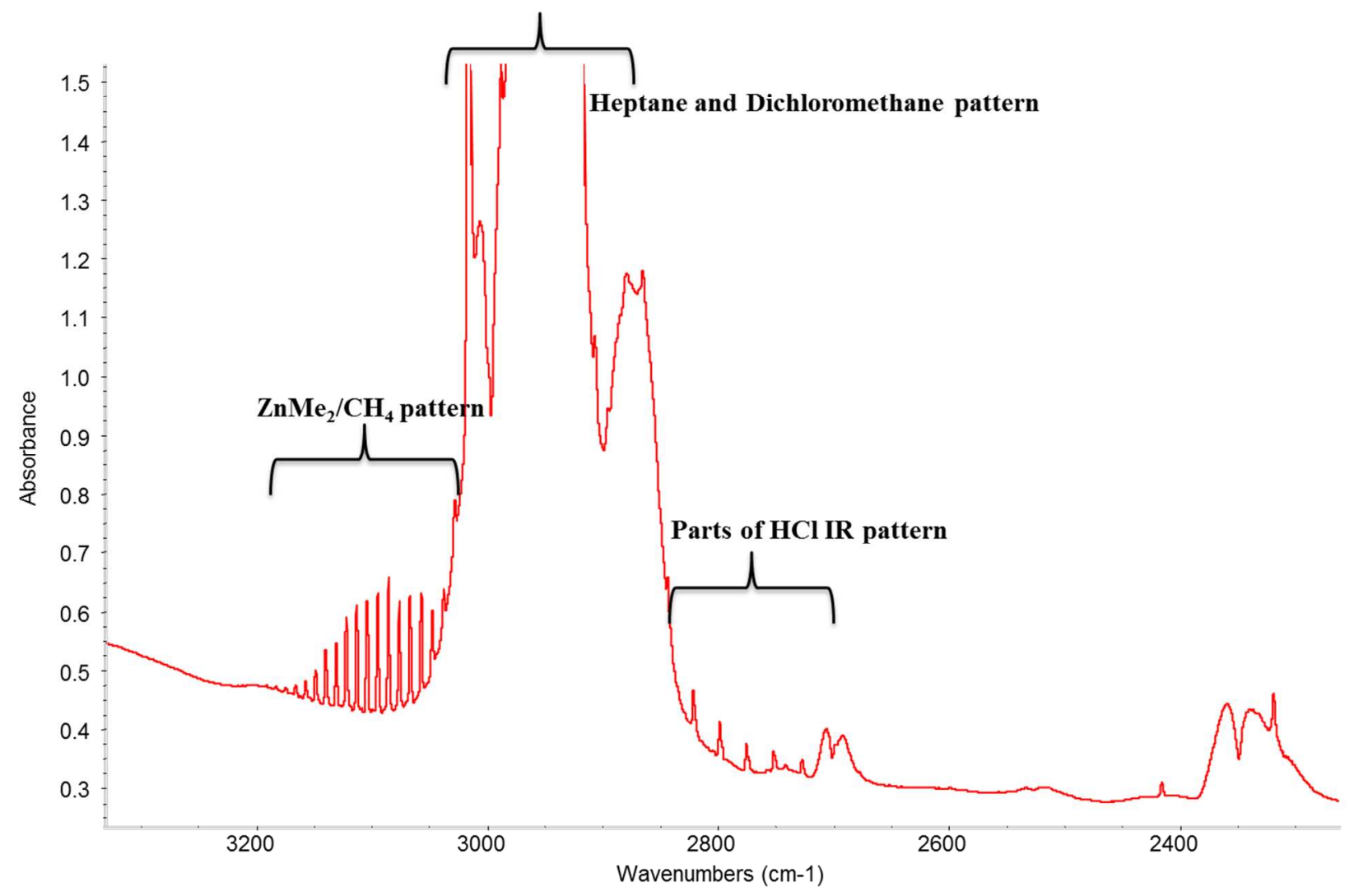

Figure S11: IR spectrum of the evolved gases during the reaction of 1 with excess $\mathrm{ZnMe}_{2}$ in dichloromethane for one hour at room temperature 
Table S4: DFT-NMR ${ }^{13} \mathrm{C}$ chemical shift of the carbene and carbyne adduct species with $\mathrm{ZnCl}_{2}$ and $\mathrm{ZnMe}_{2}$.

\begin{tabular}{|l|l|}
\hline \multicolumn{2}{|c|}{ Carbene-adduct species with $\mathrm{ZnCl}_{2}$ and $\mathrm{ZnMe}_{2}$} \\
\hline Species & $\mathrm{Chemical}$ shift (ppm) \\
\hline
\end{tabular}




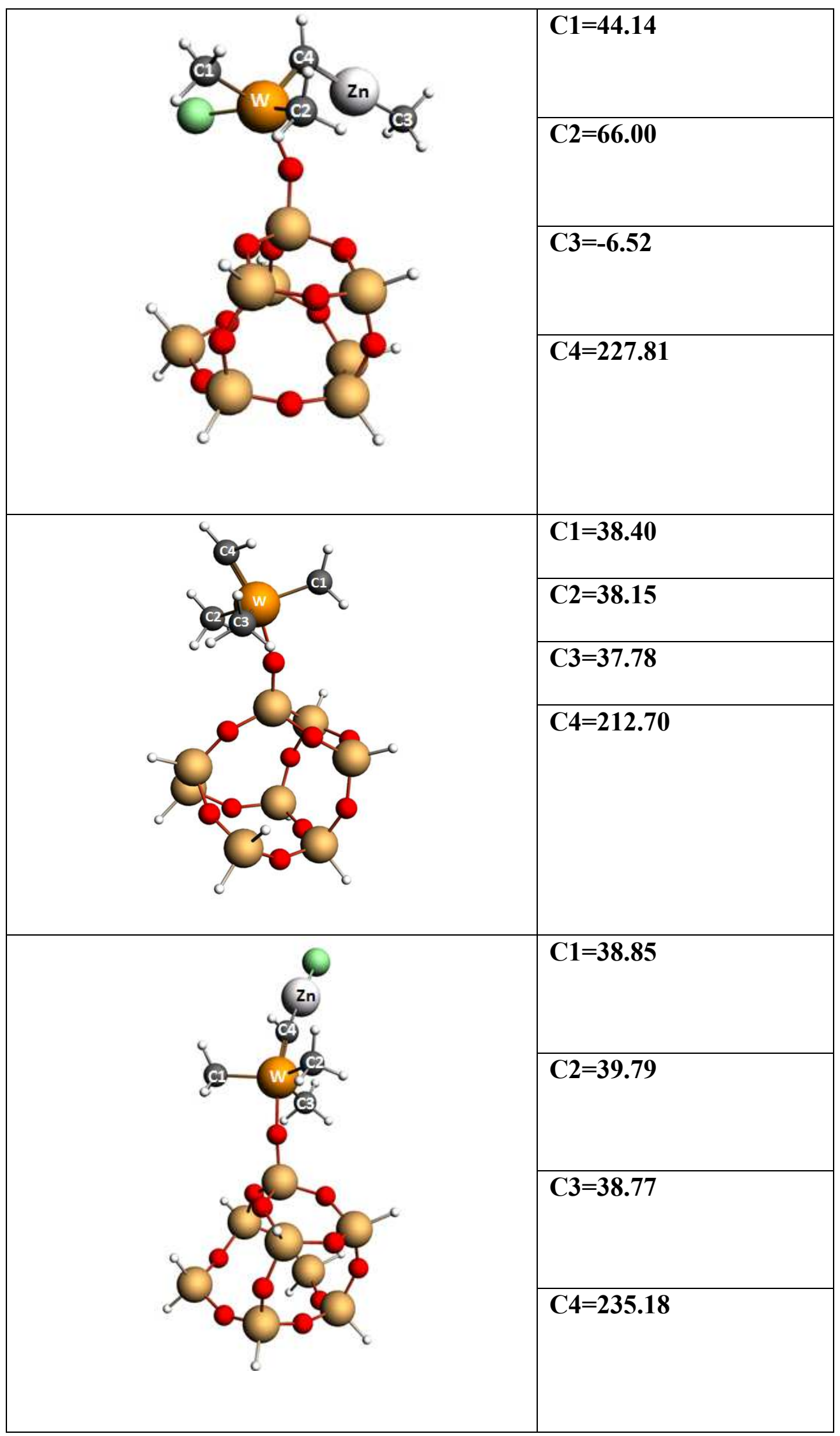




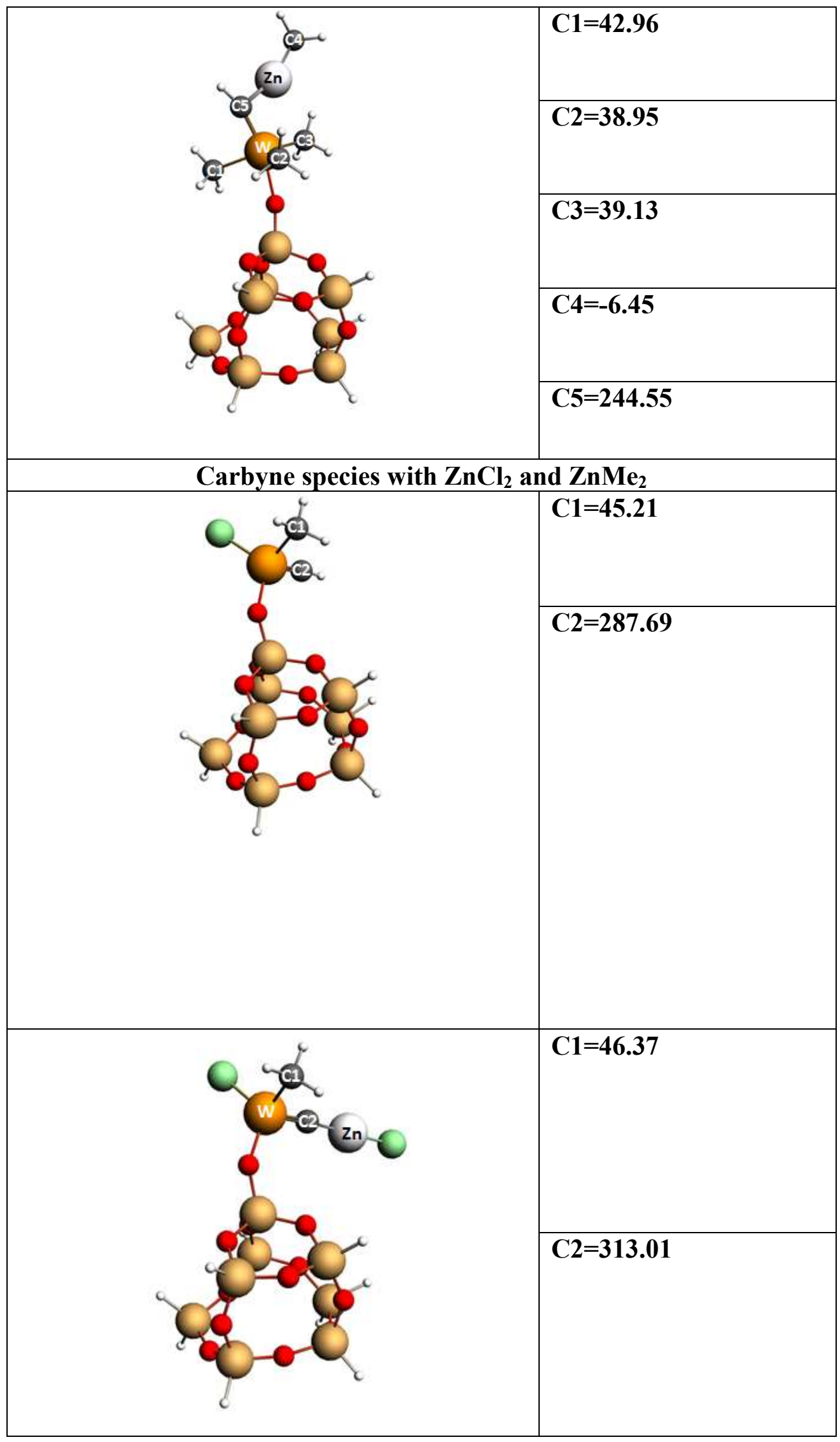




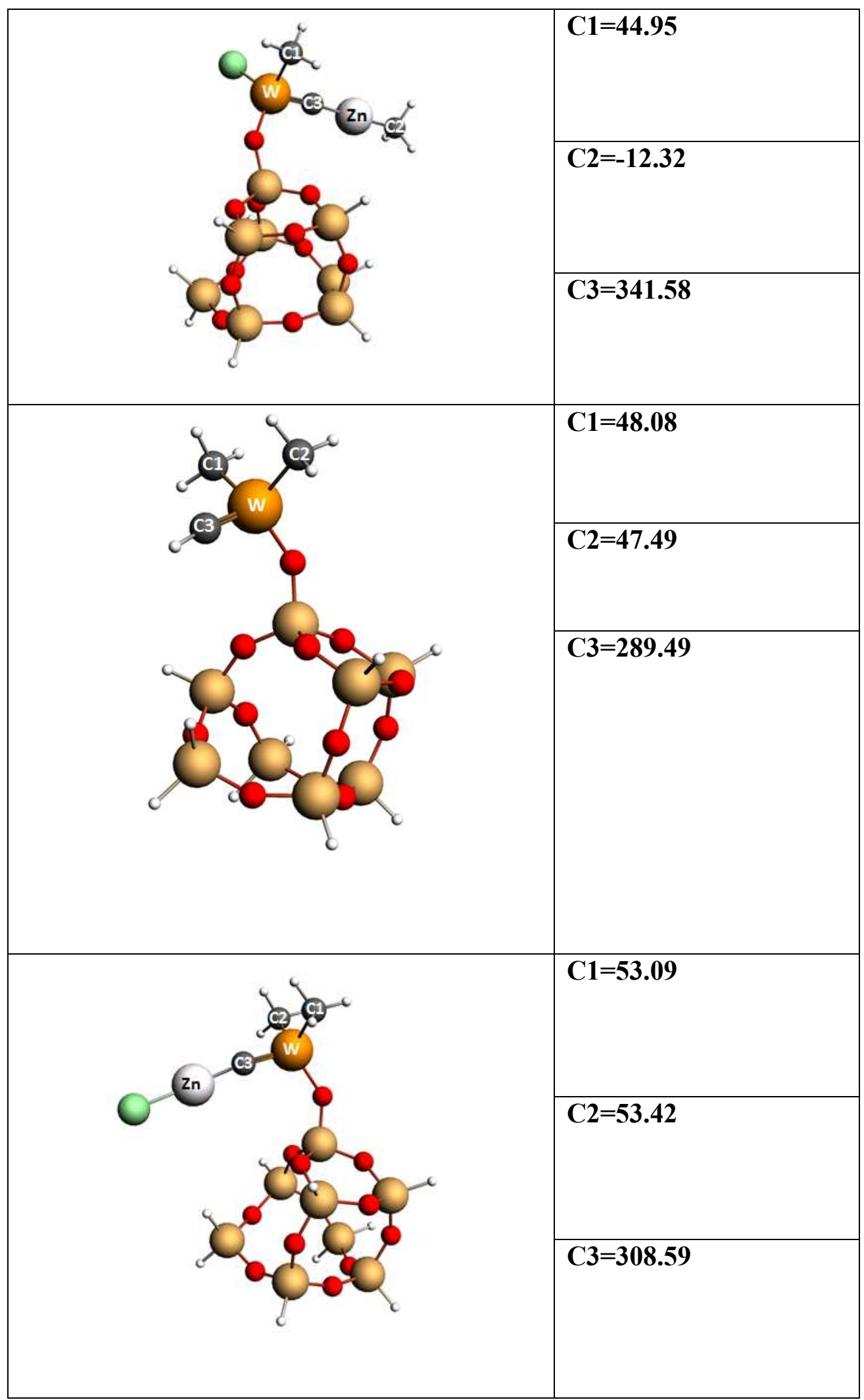




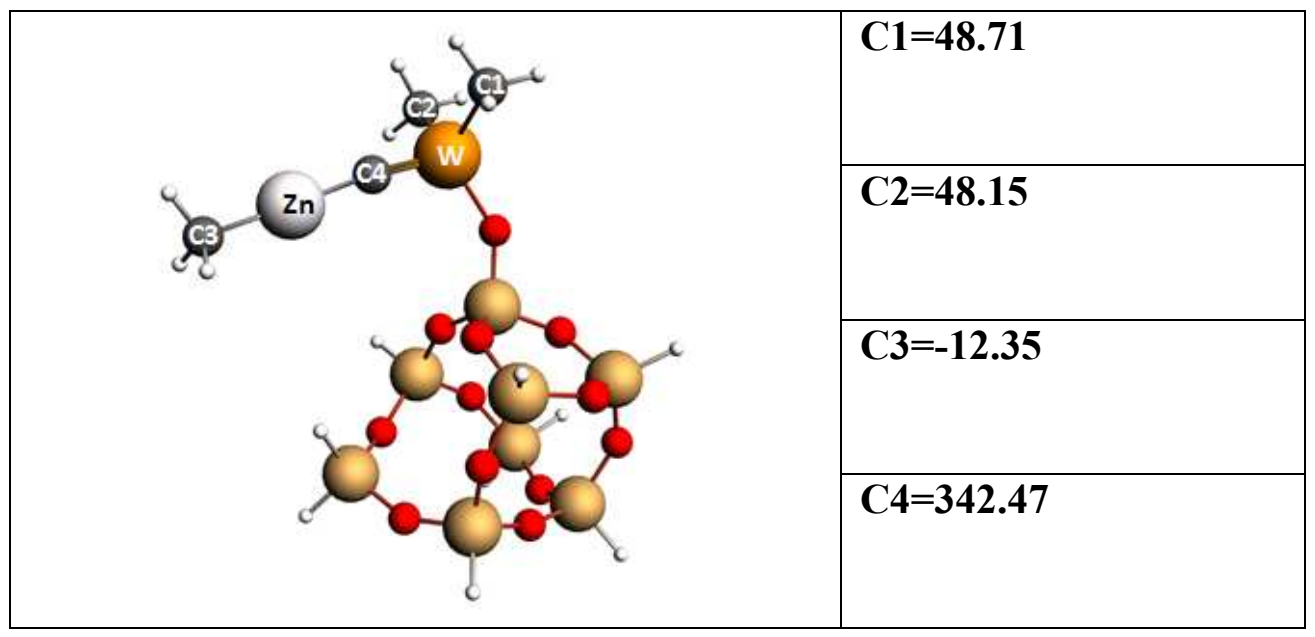

\section{Reference}

1. Samantaray, M. K.; Callens, E.; Abou-Hamad, E.; Rossini, A. J.; Widdifield, C. M.; Dey, R.; Emsley, L.; Basset, J. M., J. Am. Chem. Soc. 2014, 136, 1054-1061 